\title{
THE EXTENSIVE COLD AIR OUTBREAK OF JANUARY 24-3I, 1951
}

\author{
ALBERT MTLLER AND DONNELL H. GOULD
}

WBAN Analysis Center, U. S. Weather Bureau, Washington, D. C.

\section{INTRODUCTION}

During the last week of January a cold air outbreak occurred in the United States which, although setting few records for severity, was unusual for several reasons. (1) The intensity of the anticyclone over northwest Canada associated with the outbreak reached a central value of approximately $1065 \mathrm{mb}$. which is close to the record for the Western Hemisphere. ${ }^{1}$ (2) With the exception of the extreme southeastern portion, the entire country was covered by very cold air and, by February 2, even this remaining section was overrun. (3) The southward progress of the cold front was appreciable only at the lowest levels above the surface, principally impelled by subsi-

\footnotetext{
1 Few records are available on the maximum intensity of anticyclones over Canada. Connor [1] states that Arctic stations have reported as high as $31.0 \mathrm{in}$. (1050 mb.). A value of $1070.1 \mathrm{mb}$. was recorded at Dawson, Yukon on Jan. 6, 1909. U. S. Weather Bureau frequency charts [2] indicate that there was only one occurrence of a value of $1062.5 \mathrm{mb}$. or more during the 10-year period 1929-38. Generally accepted world record is $1079.0 \mathrm{mb}$. which occurred at Barnaul, Siberia ( $53^{\circ} \mathrm{N}$., $84^{\circ} \mathrm{E}$.) on January 23,1900 [3].
}

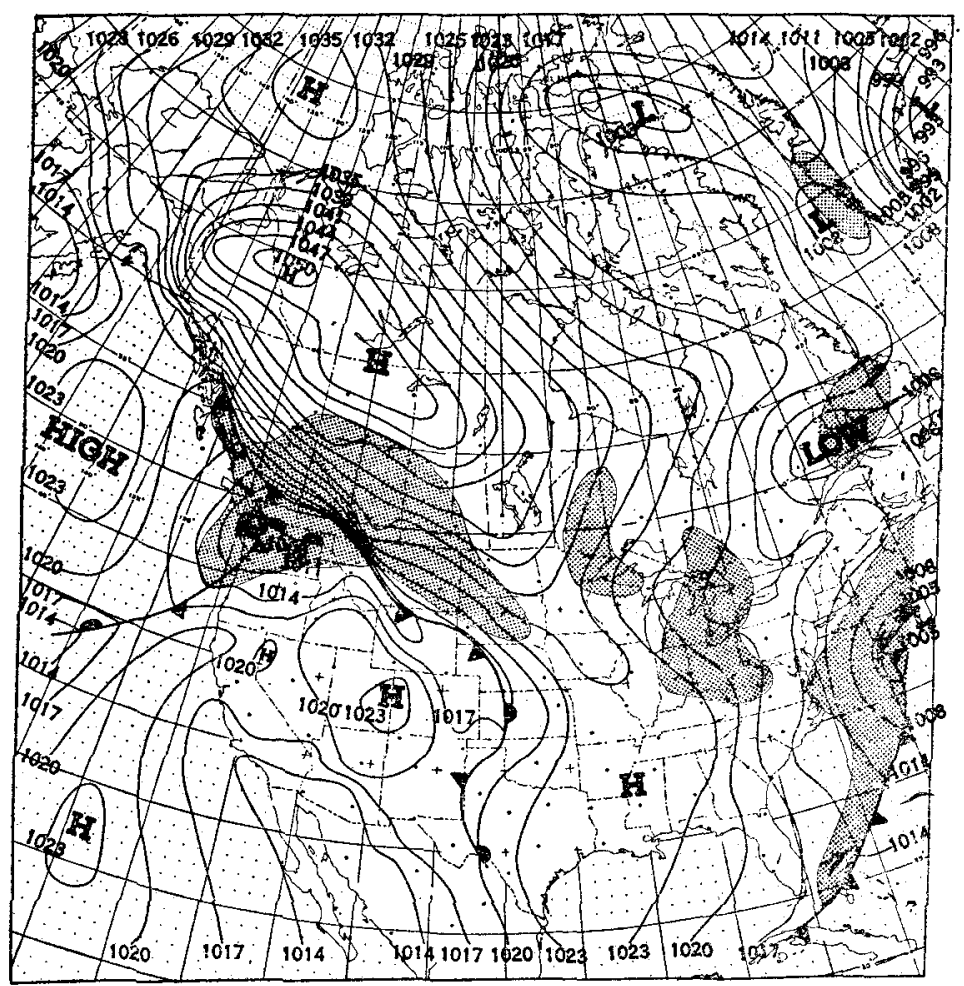

FIGURE 1.-Surface weather chart for 0030 GMT, January 26, 1951. Shading indicates areas of active precipitation. dence. This resulted in a very shallow, very cold air mass covering much of the country during several days. Overrunning by warm, moist air, above this shallow cold air, gave rise to widespread precipitation and, especially, to hazardous sleet and freezing rain east of the Rockies.

\section{HISTORICAL DEVELOPMENT}

The surface chart of January 26, 1951, 0030 GMT (fig. 1), represents the synoptic situation shortly before the intense cold air made its incursion into most of the United States and before the High in Canada reached its maximum intensity. The weak Low in the northwest corner of the country moved eastward from the Pacific Ocean and helped initiate the cold outbreak. Prior to this time, however, there were other important developments. The High over northwest Canada had been increasing slowly in intensity since January 22

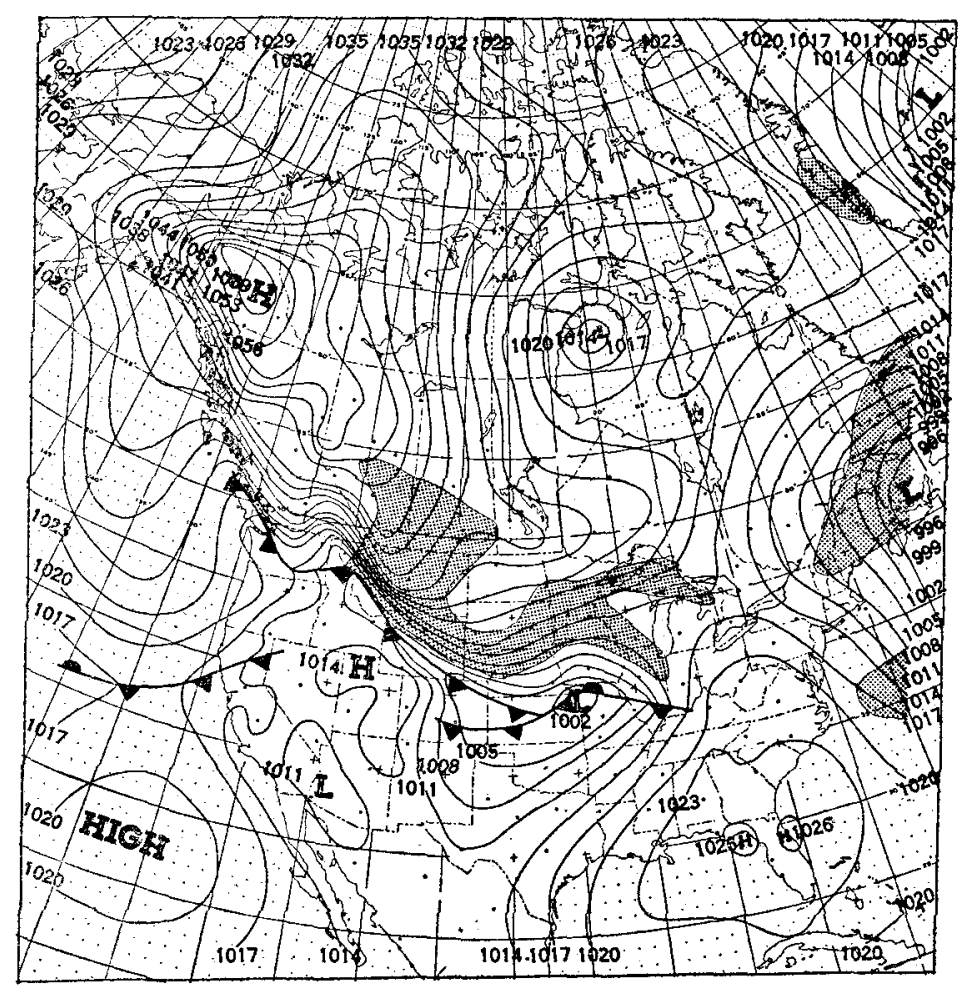

Figure 2.-Surface weather chart for 0030 GMT, January 27, 1951. 
(table 1) and the ridge which is shown over the Gulf of Alaska (fig. 1) replaced a rapidly-filling, once intense, cyclone.

On January 27 (fig. 2), the Low from the Pacific was moving rapidly eastward across the Plains until, on the following day (fig. 3), it dissipated off the Atlantic coast. By then the cold air had extended across the entire country but its southward progress, except in the Central Plains region, had been confined to the area north of $45^{\circ} \mathrm{N}$. It should be noted also that on that day the High over northwest Canada reached its maximum intensity of approximately $1065 \mathrm{mb}$.

On January 29 (fig. 4), a High cell appeared in Montana which moved rapidly eastward on the following days. The erratic movement of this center as it passed over the Great Lakes was interesting in that it dramatically emphasized the importance of these inland water bodies as a heat source during the winter months. As the High center approached Lake Michigan on January 30 (fig. 5), it decelerated markedly and another center began to form to the northeast of Lake Huron. By January 31 (fig. 6), a remnant of the western center continued to persist west of Lake Michigan even as the new center began accelerating toward the east. An examination of the 700-mb. chart for these days (figs. 14 and 15) indicates that the cold air continued its eastward movement uninterruptedly. It must be assumed then that the apparent "jump" of the surface center was caused by warming in the lowest layers in the Great Lakes area.

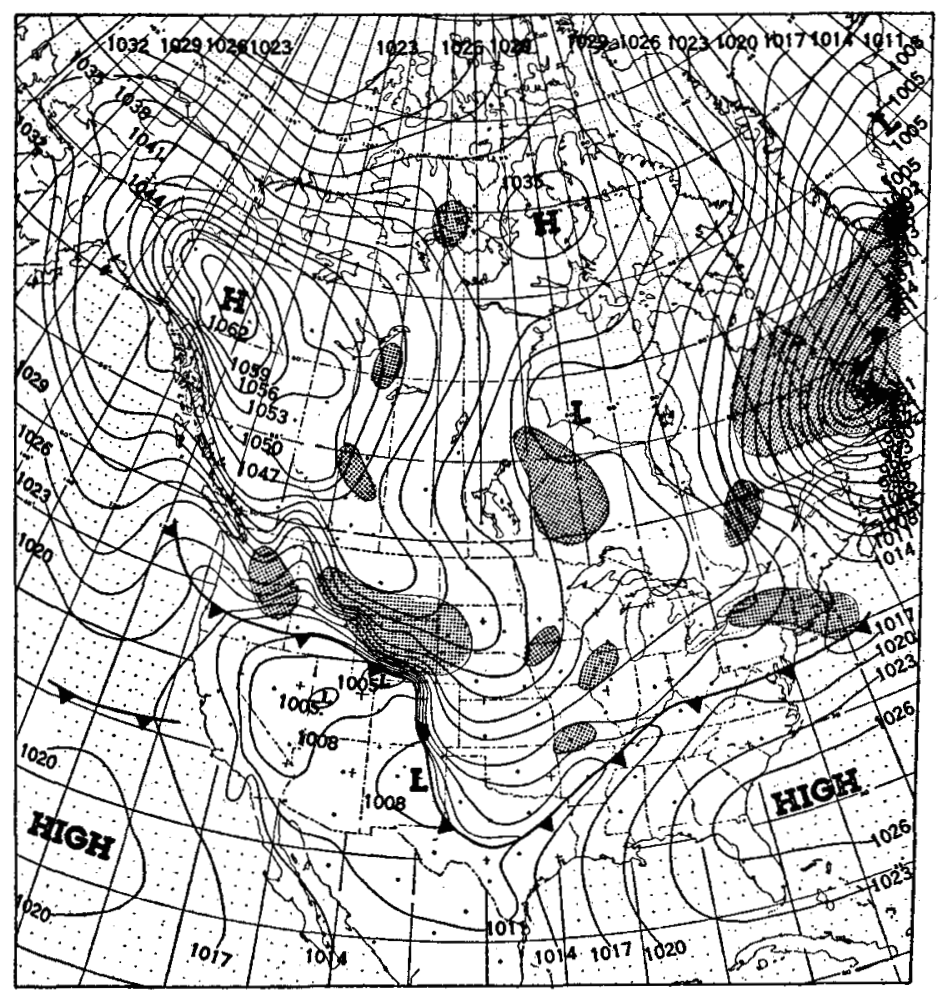

FIGURx 3.-Surface weather chart for 0030 GMT, January $28,1951$. 934723-51-3

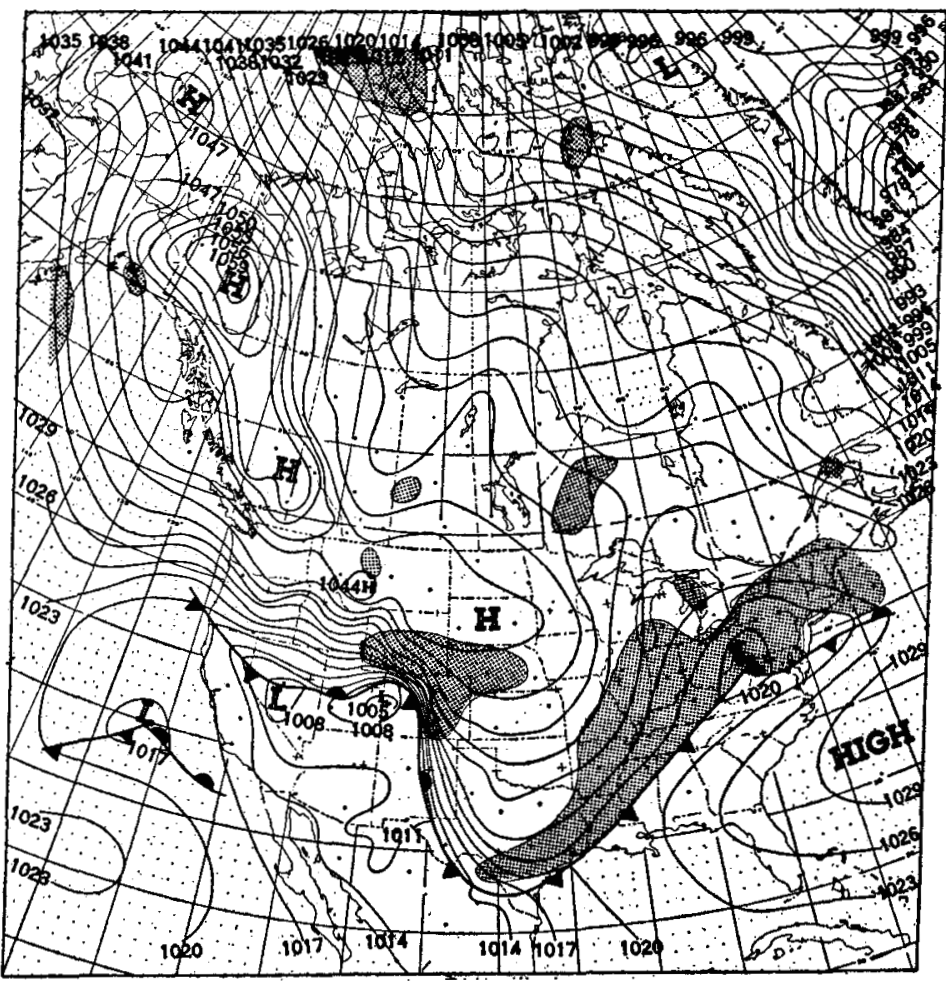

FIG URE 4.-Surface weather chart for 0030 GMT, January 29, 1951.

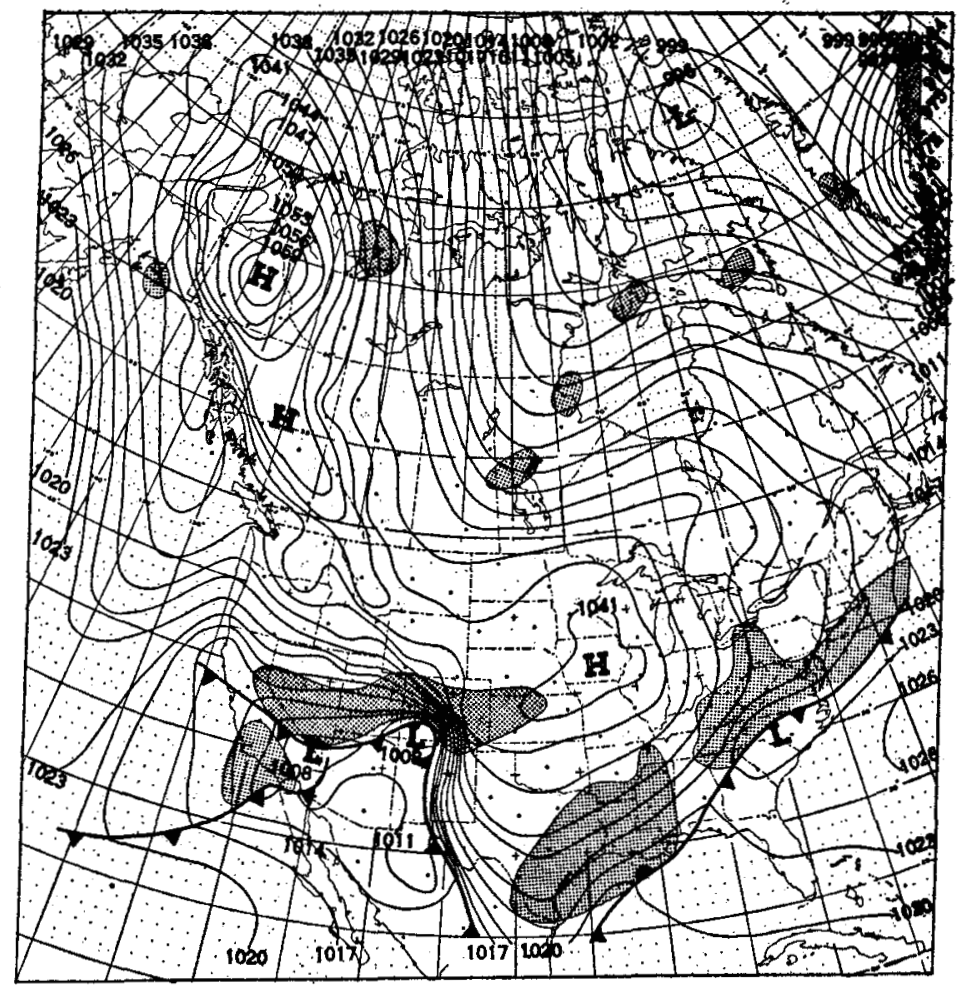

FIGURE 5.-Surface weather chart for 0030 GMT, January 30, 1951. 


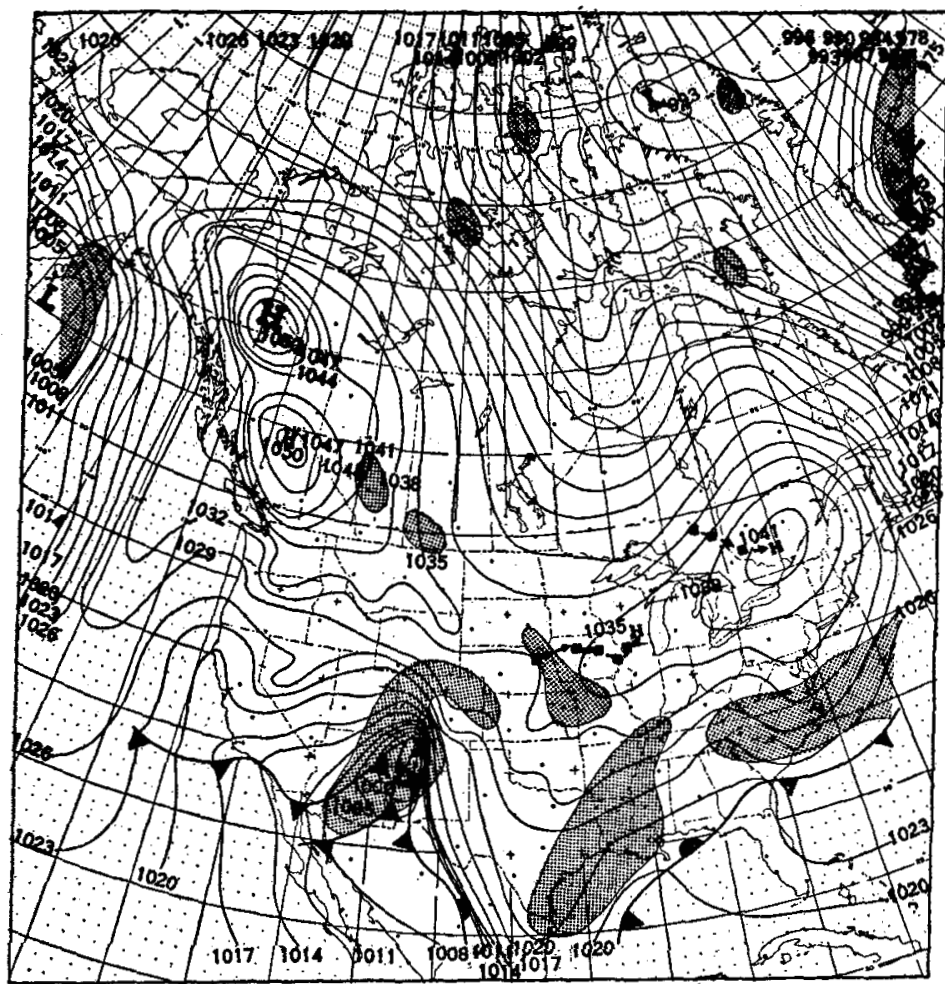

Figure 6.-Surface weather chart for 0030 GMT, January 31, 1951. Squares indicate 6-hourly positions of High.

The cyclone that started the final southward plunge of the cold air appeared on January 29 , to the west of the southern California coast (fig. 4). After traveling inland, it moved eastward until it arrived in northern New Mexico on January 31 (fig. 6). Here it weakened and moved slowly southeastward, but another Low, associated with the same trough aloft, appeared less than 18 hours later in southern Mississippi. This Low gradually intensified and moved northeastward bringing the cold air southward behind it. By 1200 GMT of February 2, the cold air had invaded the Florida peninsula, the last section of the country to feel the outbreak of frigid air.

TABLI 1.-Central pressure values of Canadian anticyclone at $0090 \mathrm{GMT}$

\begin{tabular}{|c|c|c|c|c|c|c|}
\hline $\begin{array}{l}\text { Date (January 1951) } \\
\text { Pressure (mb.) }\end{array}$ & $\begin{array}{r}20 \\
1,034\end{array}$ & $\begin{array}{r}21 \\
1,042\end{array}$ & $\begin{array}{r}22 \\
1,037\end{array}$ & $\begin{array}{r}23 \\
1,044\end{array}$ & $\begin{array}{r}24 \\
1,053\end{array}$ & $\begin{array}{r}25 \\
1,052\end{array}$ \\
\hline $\begin{array}{l}\text { Date (January 1951) } \\
\text { Pressure (mb.) }\end{array}$ & $\begin{array}{r}26 \\
1,051\end{array}$ & $\begin{array}{r}27 \\
1,061\end{array}$ & 1,065 & $\begin{array}{r}29 \\
1,060\end{array}$ & $\begin{array}{r}30 \\
1,060\end{array}$ & \\
\hline
\end{tabular}

\section{DEVELOPMENT OF THE INTENSE ANTICYCLONE}

An intensifying polar anticyclone existed over the Canadian Northwest for several weeks. The variations of the central pressure value are shown in table 1. Although much of the intensification that occurred prior to January 26 might be attributed to the effects of radiational cooling at the surface [4], the upper-air soundings at Whitehorse,

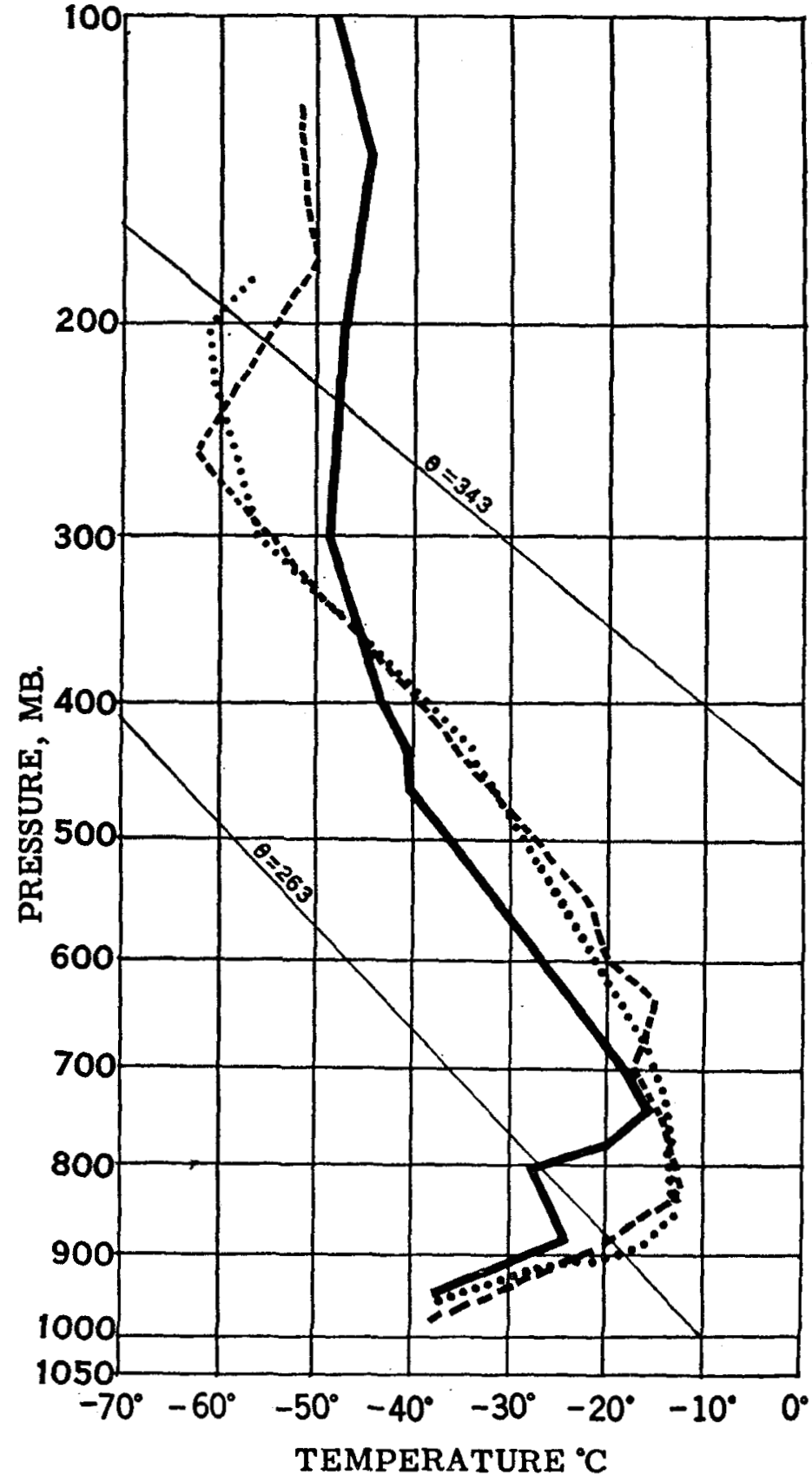

Figure 7.-Radiosonde observations at Whitehorse, Yukon, for 0300 GMT, January 26, 1951 (solid line); 0300 CMT, January 27, 1951 (dashed line); and $0300 \mathrm{GMT}$, January 28, 1951 (dotted line).

Yukon and Norman Wells, District of Mackenzie (figs. 7 and 8), observational stations on a line passing through the center of the anticyclone, would refute any such claim for the sharp increase in pressure that occurred after that date. The temperature sounding at Whitehorse showed marked warming between January 26 and 27 below 360 mb. Similarly, warming was observed at Norman Wells below $570 \mathrm{mb}$. Yet, the sea level pressure at Whitehorse and Norman Wells rose approximately $6 \mathrm{mb}$. and $2 \mathrm{mb}$, respectively, between these days. It would thus appear 


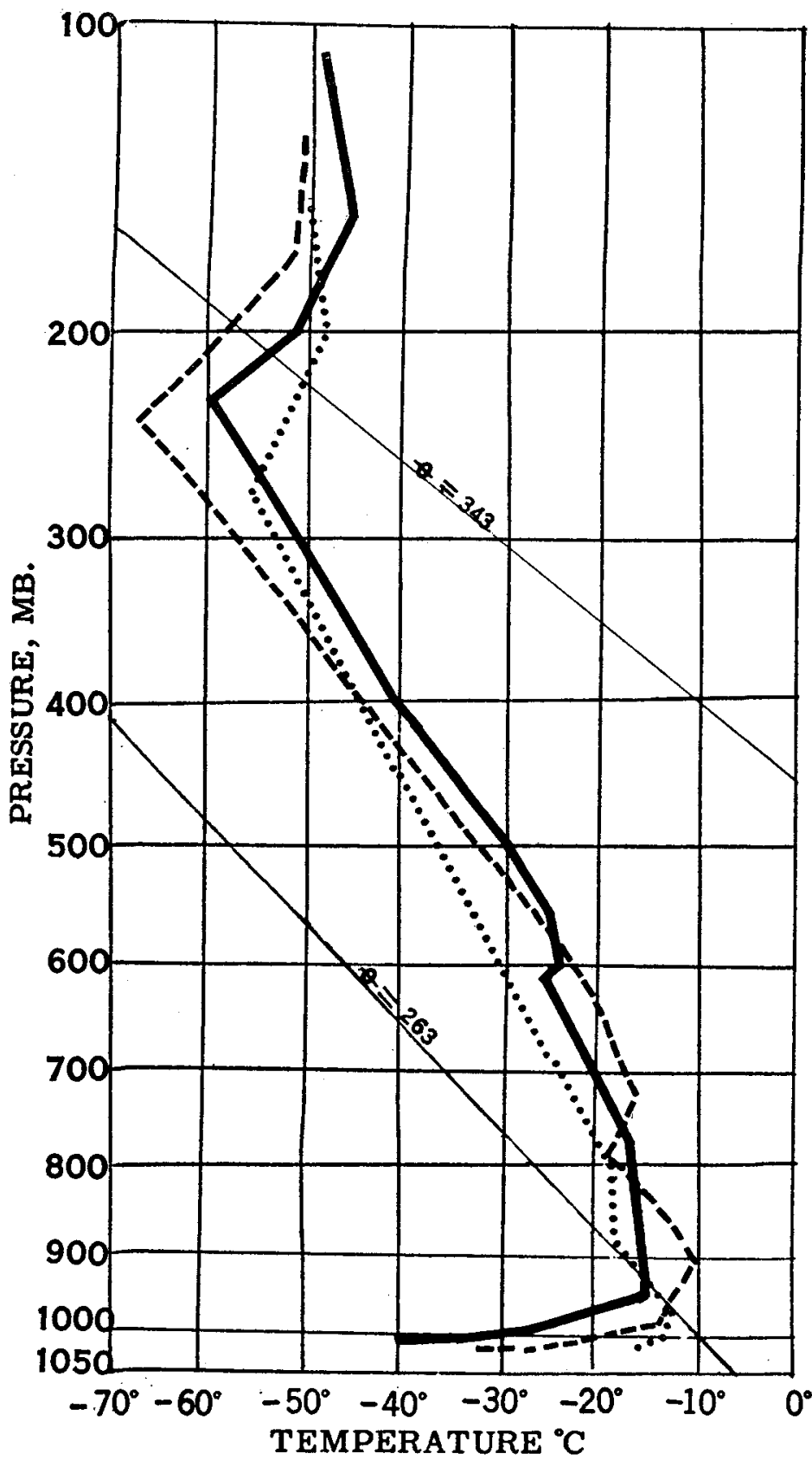

Figure 8.-Radiosonde observations at Norman Wells, District of Mackenzie, for 0300 GMT, January 26, 1951 (solid line); 0300 GMT, January 27, 1951 (dashed line); and 0300 GMT, January 28, 1951 (dotted line).

that other effects were of prime importance in these final stages of intensification.

One such cause might be the strong stratospheric cooling that occurred over much of the area, either brought on by advection [5] at these high levels or by radiation. However, one of the most striking effects that could be readily ascertained was the apparent association of the welldeveloped dynamic ridge aloft with the surface intensification. It can be seen from the 500-mb. chart of January 27 (fig. 10) that there was a well-developed "warm" ridge directly above the surface High position at approximately the time of the maximum intensity. This is in agreement with previous observations of very intense polar anticyclones [5].

The warm ridge at this level first appeared as a strong "blocking" High to the southwest of the Aleutian Chain. It gradually intensified northward into the Bering Straits where a separate cell broke off. It then proceeded eastward over the Beaufort Sea and finally southward, passing over the northwest corner of Canada. Figures 9 through 12 illustrate the movement of the High at $500 \mathrm{mb}$. during the latter part of the trajectory. It will be noted also from these figures that great warming at $500 \mathrm{mb}$. accompanied the migration, particularly in the center of the High and on the left-hand side of the path of movement.

\section{TRAJECTORY OF THE COLD AIR}

The unusual trajectory of the cold air out of Canada is illustrated by the flow patterns that existed on the 700-mb. charts of the days under discussion (figs. 13, 14, and 15). The important features of the pattern of January 26 were the extensive, strong, northerly flow that was predominant over most of central Canada, the trough that existed over southwest Canada, and the generally westerly flow over the entire United States. The events which led to this pattern included the following: The ridge development over northwest Canada increased the northerly flow to the east of it. At the same time a ridge was intensifying about 400 miles off the northwest coast. Between these two regions the cold trough in southwest Canada intensified.

The cold air in the trough originated in northern Alaska, having been advected southward around an intense Low over the Gulf of Alaska. Eventually the Low became a "cold" type and filled, but not before a remnant of it, accompanied by a core of cold air, moved inland. This initial surge from the Pacific was later reinforced by a tongue of cold air from central Canada. On January 26 (fig. 13), the cold air is seen to be moving southeastward out of Canada into the northwestern States.

Meanwhile, over the United States, except for a filling trough along the east coast, the wave amplitude of the westerlies was quite small. Thus by January 28 (fig. 14), the cold air that had entered the northwestern States had swept rapidly across the northern tier of States at $700 \mathrm{mb}$. evidencing very slight southward displacement.

On January 30 (fig. 15), the trough changed its orientation to northeast-southwest and began to accelerate. When that occurred the cold air was then advected southward to the rear of the trough and eventually covered the southern extremities of the country.

\section{EFFECTS ON WEATHER OVER THE UNITED STATES}

A concept of the amount of subsidence that took place east of the Rockies within the cold air may be had from 


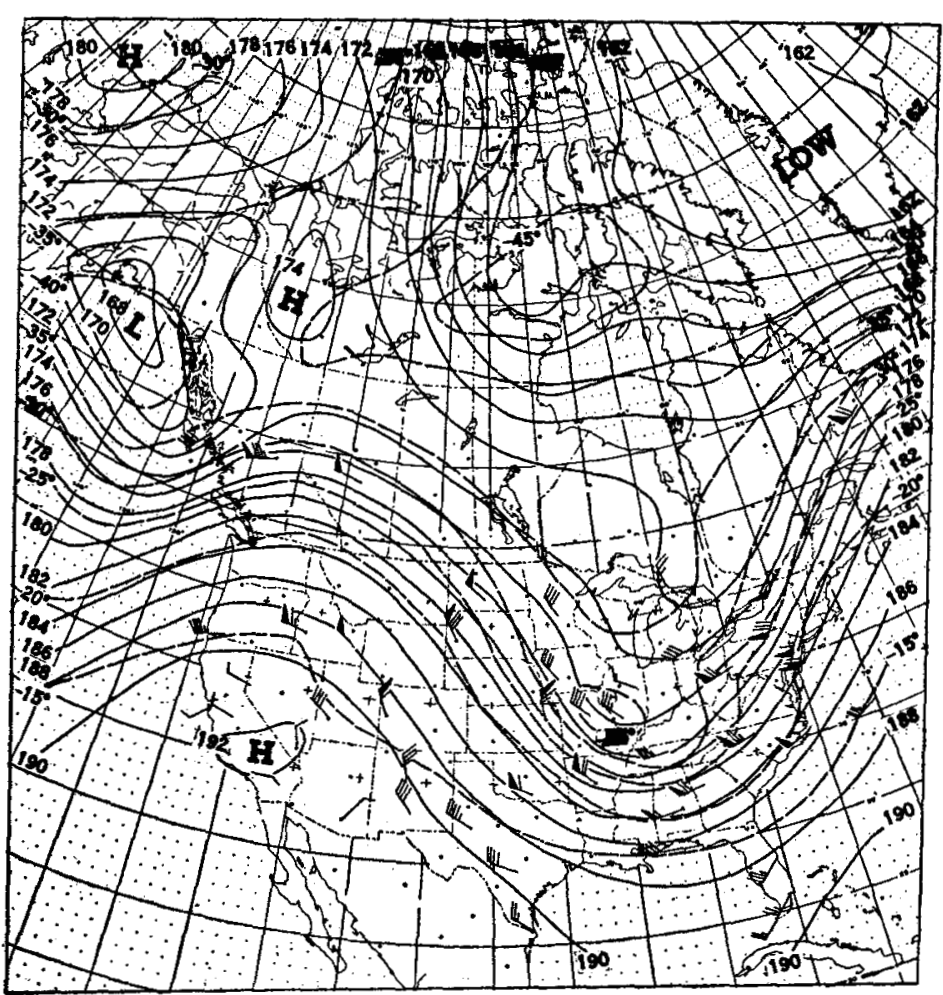

FigURx 9. - 500-mb. chart for 0300 GMT, January 25, 1951. Contours (solid lines) at 200-ft. Intervals are labeled in hundreds of geopotential feet. Isotherms (dashed lines) are at Intervals of $5^{\circ} \mathrm{C}$. Barbs on wind shafts are for speeds in knots (pennant $=50$ knots, full bar $b=10$ knots, and half-bar $b=5$ knots).

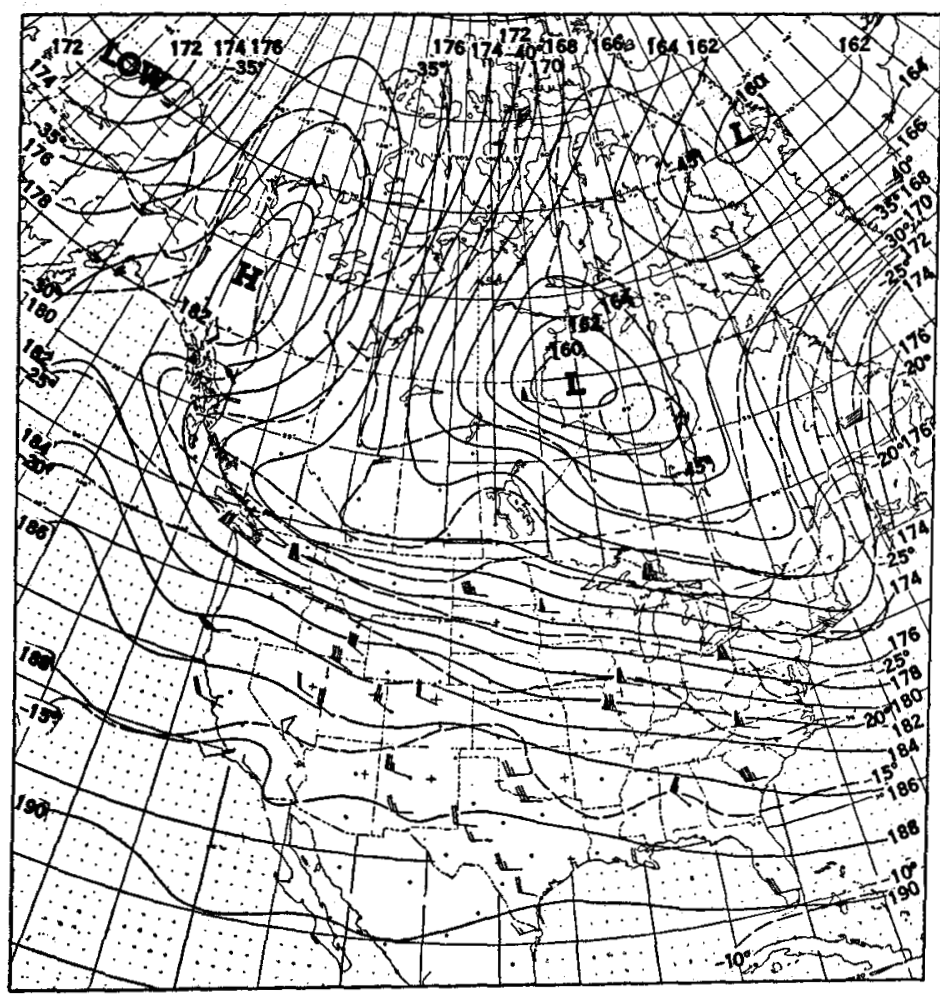

FicuRe 10,-500-mb. chart for 0300 GMT, January 27, 1951.

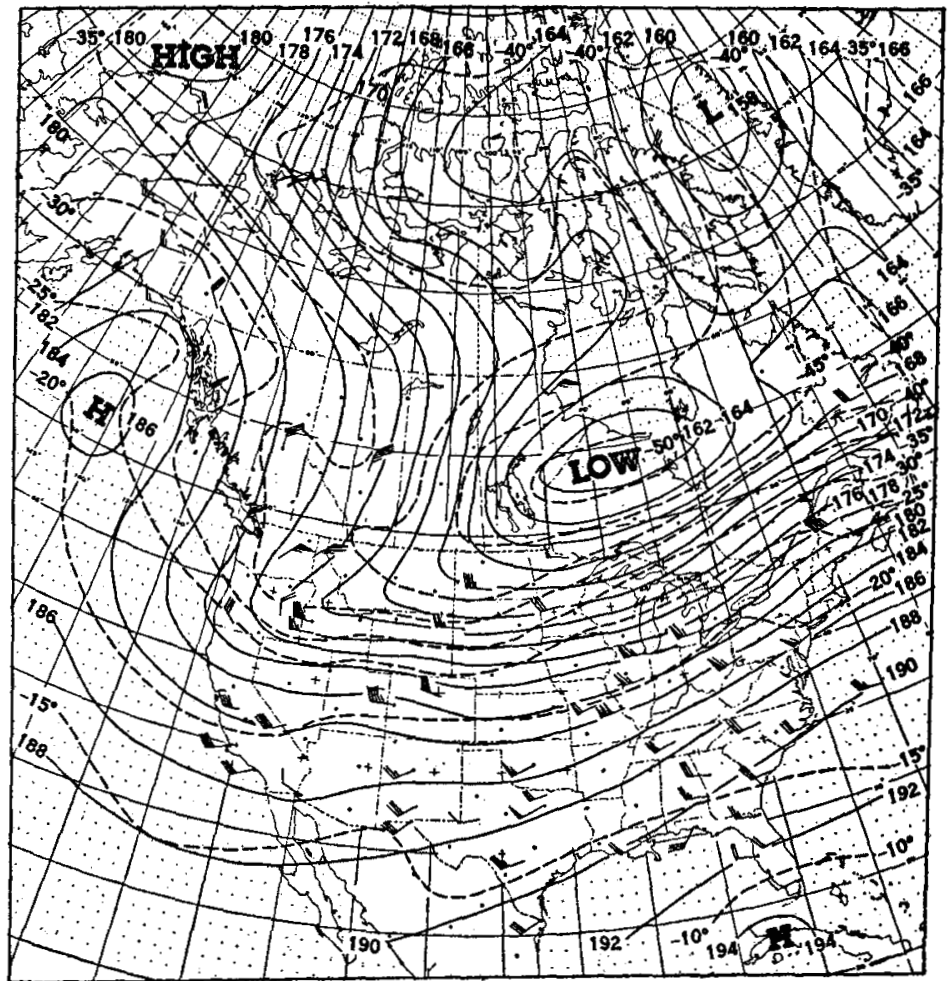

Fig URE 11, 500-mb. chart for 0300 GMT, J\&nuary 29, 1951.

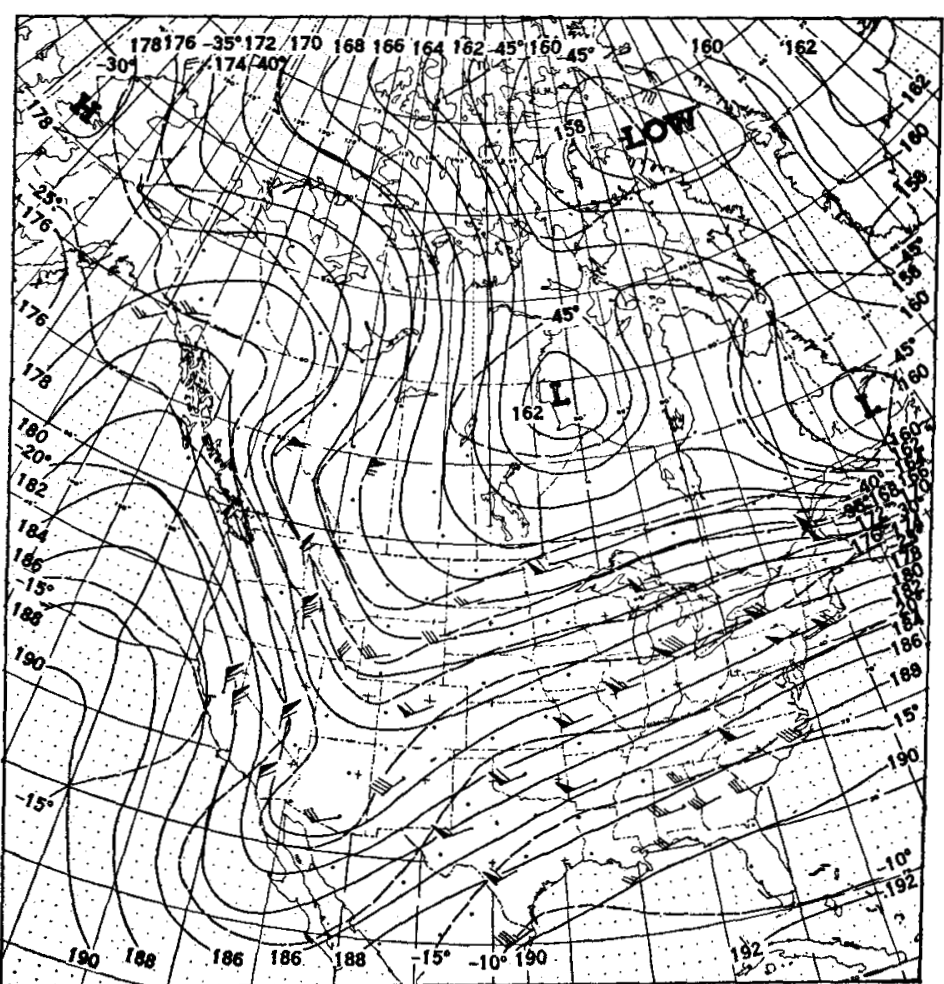

FIGURE 12.-500-mb. chart for 0300 GMT, January 31, 1951. 


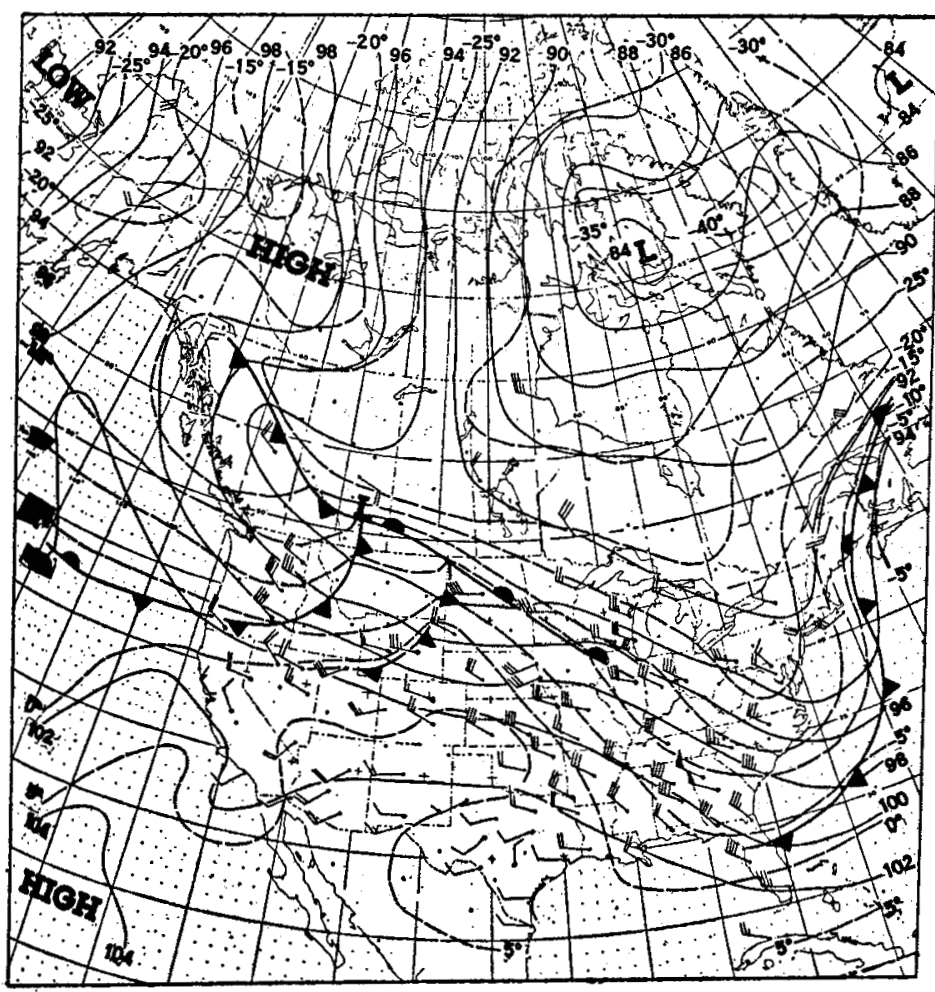

Figuke 13.-700-mb. chart for 1500 GMT, January 26, 1951.

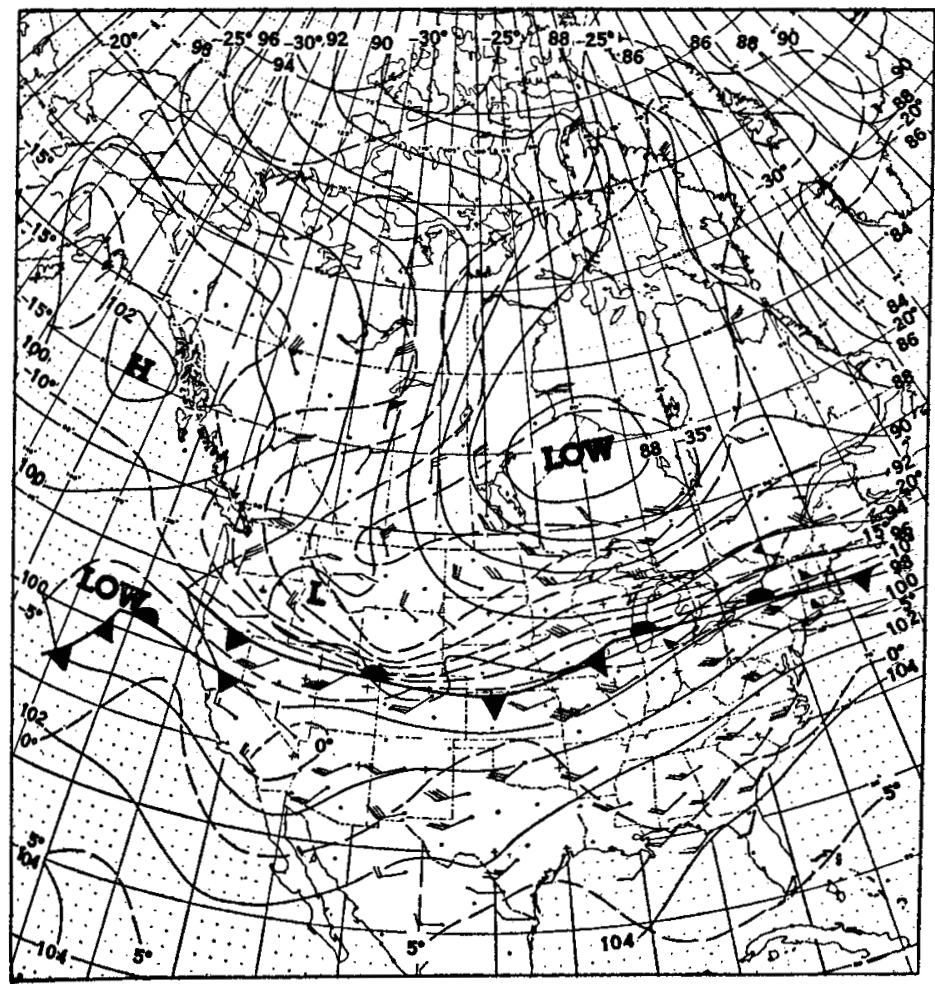

FIGURE 14,-700-mb. chart for 1500 GMT, January 28, 1951.

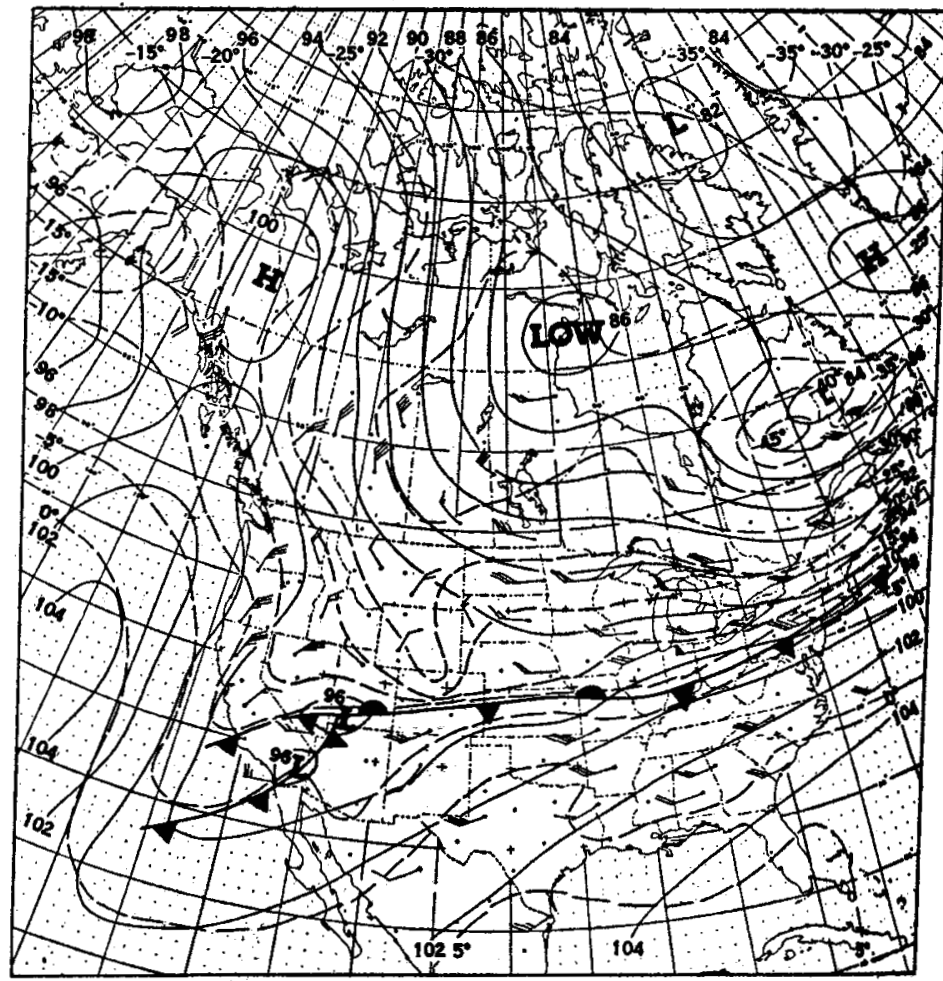

Fraukn 15.-700-mb. chart for 1500 GMT, January 30, 1951.

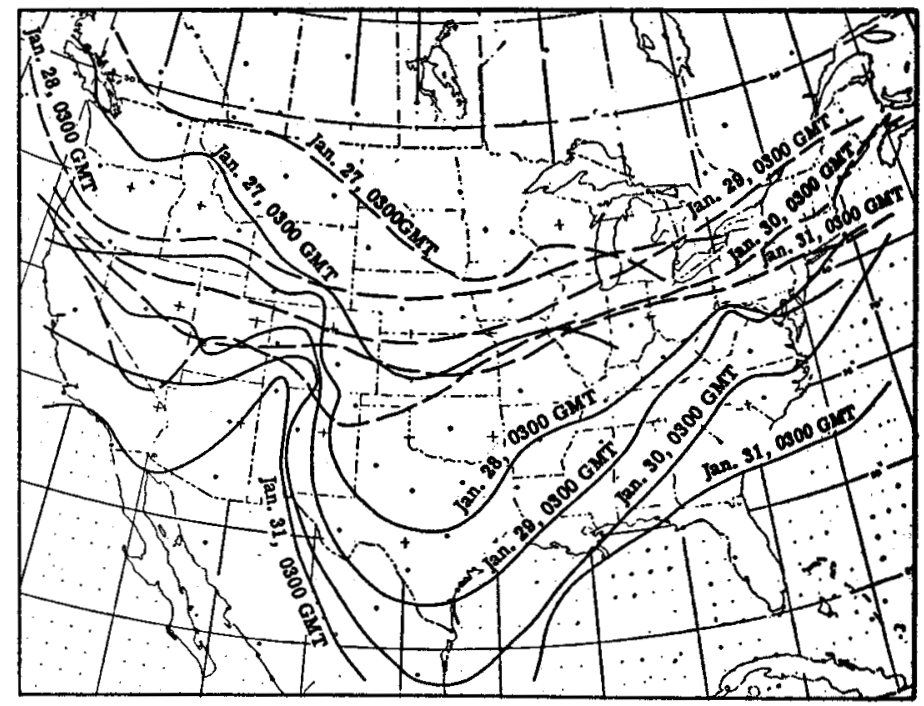

FIGURE 16.-Frontal positions at the surface and $700-\mathrm{mb}$. levels. Solid lines reprecent surface positions, dashed lines 700-mb. positions. 


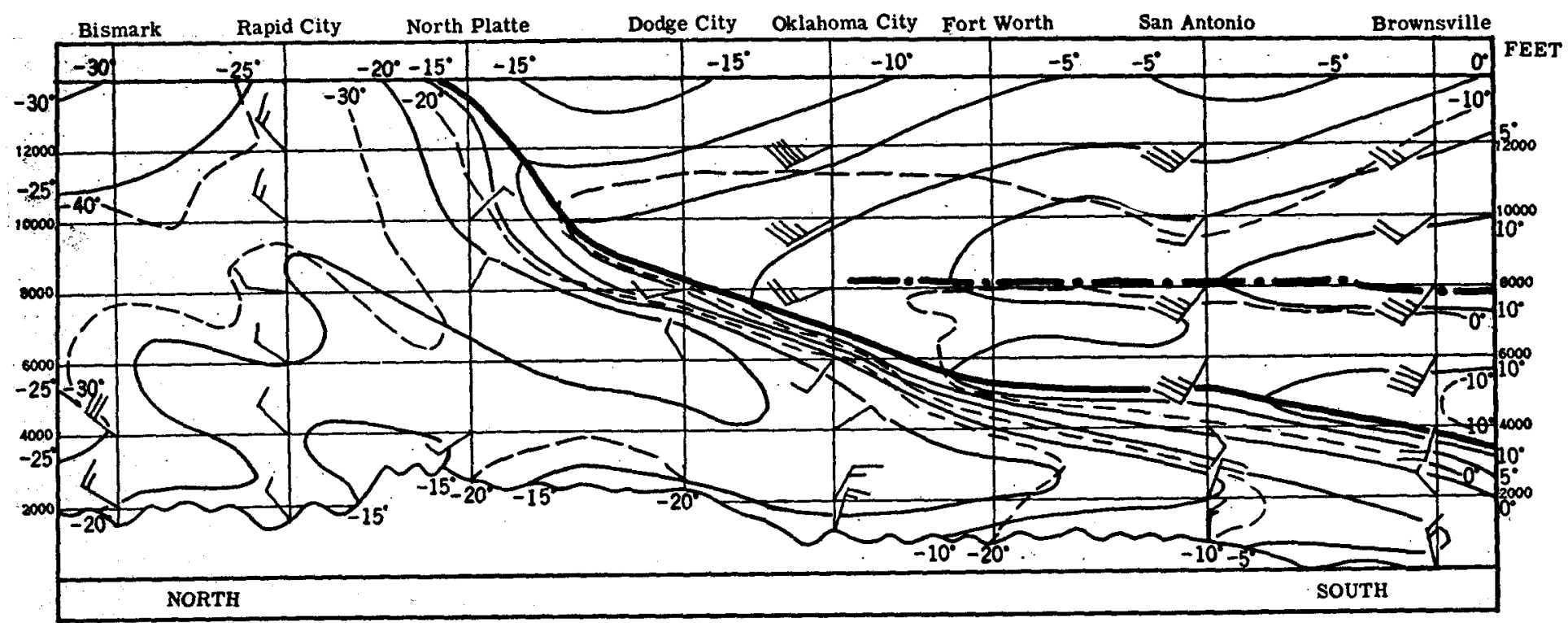

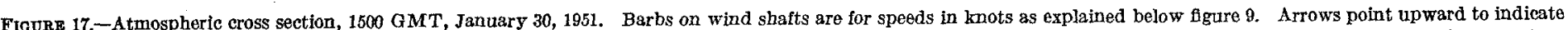

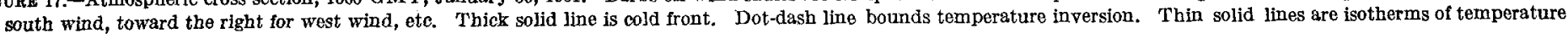
in ${ }^{\circ} \mathrm{C}$. Dashed lines are isotherms of dew point in ${ }^{\circ} \mathrm{C}$.

figure 16 which depicts the frontal positions at the surface and at the 700-mb. level during most of the period. The very gradual frontal slope and the presence of warm, very humid air riding above it is illustrated by the vertical atmospheric cross section of figure 17 . The latter illustration typifies conditions that existed over the entire eastern half of the country during the last few days of the month.

Sleet and freezing rain were not only severe in many places but covered large areas, resulting in widespread damage. For example, the Telephone Company reported that disruption to its service, particularly in the southern States, was the most extensive in its history, with $\$ 8,000$,000 damage to its system in the States of Alabama, Mississippi, and Tennessee alone. The dimensions of the precipitation area are indicated by the fact that, on January 28, 29, 30, and 31, the number of States in which 24-hour rainfall amounts were not recorded varied only between one and six.

The temperature gradient across the cold front can be seen in figure 17 , but its significance may be more readily visualized by the changes in temperature that occurred at certain stations after the front passed over them. For example, from a high of $79^{\circ} \mathrm{F}$. the temperature at Goodland, Kans., dropped $49^{\circ}$ F. within 6 hours after the front had passed and continued to fall to $3^{\circ} \mathrm{F}$., recorded approximately 18 hours after the frontal passage. Corpus Christi, Tex., registered an early afternoon temper- ature of $73^{\circ} \mathrm{F}$. which fell $21^{\circ} \mathrm{F}$. in 3 hours and hovered near freezing all the next day.

It was not until February 2, after the formation and rapid movement northeastward of a deep cyclone along the east coast had deepened the cold air and eliminated the extensive overrunning of warm air, that the weather began to clear.

\section{REFERENCES}

1. A. J. Connor, "Climate of Canada", Handbuch der Klimatologie, Band II, Teil J, Verlag der Gebrüder Borntraeger, Berlin, 1936.

2. U. S. Weather Bureau, Frequencies of Intensities of Highs and Lows, 1943 (unpublished). (Preliminary results of this study of frequency of Highs and Lows in the Northern Hemisphere by $5^{\circ}$ squares was reported by L. W. Sheridan, Transactions of the American Geophysical Union, vol. 26, Part I, Aug. 1945, p. 49-57.)

3. R. Scherhag, Neue Methoden der Wetteranalyze und Wetterprognose, Springer-Verlag, Berlin, 1948, p. 126.

4. H. Wexler, "Cooling in the Lower Atmosphere and the Structure of Polar Continental Air", Monthly Weather Review, vol. 64, No. 4, Apr. 1936, p. 122-136.

5. H. Wexler, "Anticyclones", Compendium of Meteorology, American Meteorological Society, 1951. (In press.) 